\title{
UJI AKTIVITAS ANTIBAKTERI EKSTRAK ETANOL KULIT BATANG MANGGA KWENI (Mangifera odorata Griff) TERHADAP Escherichia coli ATCC 25922 DAN Staphylococcus aureus ATCC 25923
}

(The Antibacterial Activity Essay of Ethanol Extract Kweni Mango Bark (Mangifera odorata

Griff) Againts Escherichia coli ATCC 25922 and Staphylococcus aureus ATCC 25923)

\author{
Wuri Prihatiningtyas, Yeni Mariani, H.A. Oramahi, Fathul Yusro, Lolyta Sisillia \\ Fakultas Kehutanan Universitas Tanjungpura Jalan Imam Bonjol Pontianak 78124 \\ Email : wuriprihatiningtyas94@gmail.com
}

\begin{abstract}
The aims of this research are to determine the secondary metabolite content found in the ethanol extract of kweni mango bark (Mangifera odorata Griff) and analyze its potency as a natural antibacterial against Escherichia coli and Staphylococcus aureus. The research was started by maceration process using $96 \%$ ethanol solvent, then evaporated at $40-50^{\circ} \mathrm{C}$ and obtain yield of 20,61\% with powder content of 8,34\%. Furthermore, phytochemical screening was performed qualitatively to determine the secondary metabolite of the extract. The results showed that ethanol extract of M. odorata Griff bark contained secondary metabolites such as alkaloids, flavonoids, saponins, tannins, terpenoids and phenolics. In this study antibacterial activity was carried out using disc diffusion method in Plate Count Agar media and incubated for 24-48 hours. The results showed that the largest diameter of inhibitory zones formed at a concentration of $15 \mathrm{mg} / \mathrm{ml}$ for $S$. aureus was $12,33 \mathrm{~mm}$ with strong classified and for E. coli bacteria with a concentration of $200 \mathrm{mg} / \mathrm{ml}$ of 23,67 $\mathrm{mm}$ with very strong classified, and almost equal with the result shown by $30 \mu \mathrm{g}$ tetracycline as positive control, which is $25 \mathrm{~mm}$. The results of this study it can be concluded that the ethanol extract of the kweni mango bark (M. odorata Griff) is bacteriostatic.
\end{abstract}

Keywords: antibacterial activity, Mangifera odorata Griff, phytochemical screening, Escherichia coli, Staphylococcus aureus.

\section{PENDAHULUAN}

Diare merupakan salah satu penyakit klinis yang umum ditemui di Negara berkembang seperti Indonesia. Pada tahun 2008, 2009, dan 2010 terjadi peningkatan jumlah penderita diare yang menyebabkan kematian sehingga dilaporkan sebagai wabah Kejadian Luar Biasa (KLB) (Kemenkes RI, 2011). Diare dapat disebabkan oleh adanya infeksi yang berasal dari virus, parasit dan bakteri. Di Indonesia, pada umumnya diare disebabkan oleh bakteri
Escherichia coli, Staphylococcus aureus, Vibrio cholerae, Salmonella sp., Shigella sp., dan Campylobacter (Ajizah, 2004).

Secara umum serangan atau infeksi bakteri dapat diatasi dengan menggunakan antibakteri dan antibiotik (Yang et al. 2009), tetapi seiring dengan adanya peningkatan resistensi bakteri yang salah satunya disebabkan oleh penggunaan dari antibakteri dan antibiotik yang tidak tepat mengakibatkan berkurangnya 
keefektifan dan kinerja dari metode pengobatan tersebut (Candrasari et al. 2012). Berdasarkan hal tersebut, maka dilakukanlah berbagai penelitian yang bertujuan untuk menemukan antibakteri baru sebagai alternatif lain dalam mengatasi infeksi bakteri. Antibakteri baru ini diharapkan berasal dari bahan alam yang mudah didapat dengan ketersediaan yang melimpah, dapat diperbaharui serta memiliki resiko efek samping yang lebih kecil. Salah satu bahan alam yang berpotensi sebagai antibakteri adalah tumbuhan (Djajadisastra et al. 2009).

Pemanfaatan tumbuhan sebagai antibakteri telah dikenal oleh masyarakat Indonesia dalam bentuk tumbuhan obat, dimana pada umumya tumbuhan obat ini berasal dari kawasan hutan. Salah satu tumbuhan yang berpotensi sebagai tumbuhan obat antibakteri adalah mangga kweni (Mangifera odorata Griff). M. odorata Griff merupakan tumbuhan dari famili Anarcardiaceae, dimana golongan famili Anarcardiaceae dikenal memiliki senyawa fenolik yang berpotensi sebagai tumbuhan obat dan antibakteri alami. Menurut hasil penelitian Lukmandaru et al. (2012), ekstrak metanol M. odorata Griff mengandung senyawa metabolit sekunder seperti flavonoid, alkaloid, fenolik dan tanin. Dimana senyawa tanin, flavonoid, saponin, fenolik, terpenoid dan alkaloid merupakan senyawa yang mempunyai sifat antibakteri (Santoso, 2012).

Ekstraksi kulit batang $M$. odorata Griff dilakukan dengan metode maserasi yang merupakan proses ektraksi yang paling umum digunakan (Depkes RI, 2000). Dengan menggunakan pelarut yang sesuai seperti pelarut etanol yang bersifat polar, diperoleh senyawa metabolit sekunder yang bersifat polar, nonpolar dan semi polar (Poelengan et al. 2007).

Beberapa pengujian aktivitas antibakteri $M$. odorata Griff telah dilakukan dengan menggunakan bagian tanaman berupa buah dan daun. Berdasarkan penelitian, ekstrak buah $M$. odorata Griff dapat menghambat Staphylococcus aureus pada konsentrasi $50 \%$ sebesar $7 \mathrm{~mm}$ dan konsentrasi $100 \%$ sebesar 8,667 mm (Suerni et al. 2013). Selain itu, ekstrak daun $M$. odorata Griff dengan konsentrasi 10 $\mathrm{mg} / \mathrm{ml}$ juga dapat menghambat Bacillus cereus sebesar $8,9 \mathrm{~mm}$ (Muskhazli et al. 2009). Sejauh ini penelitian aktivitas antibakteri dari $M$. odorata Griff hanya pada bagian daun dan buah, namun belum dilakukan penelitian pada bagian kulit batang $M$. odorata Griff. Menurut Haygreen dan Bowyer (1989), kandungan ekstraktif dalam kulit batang kayu lebih tinggi daripada dalam kayu.

Aktivitas antibakteri dari suatu ekstrak atau senyawa dapat diketahui dengan melakukan pengujian penghambatan pertumbuhan bakteri (Dart, 1996). Metode difusi atau (disc diffusion Kirby and Bauer) merupakan metode pengujian yang umum digunakan dalam uji aktivitas antibakteri. Pada metode ini, kertas cakram yang telah berisi bahan antibakteri (ekstrak) diletakkan di atas permukaan media yang telah tersuspensi bakteri uji. Adanya zona bening pada 
permukaan media mengindikasikan hambatan pertumbuhan bakteri oleh bahan aktibakteri (Rhimou et al. 2010).

Penelitian ini menarik untuk dilakukan guna mengetahui kandungan metabolit sekunder kulit batang $M$. odorata Griff serta potensinya sebagai bahan antibakteri alami, sehingga dapat menjadi alternatif lain dalam penanganan diare yang disebabkan oleh bakteri E. coli dan S. aureus.

\section{METODE PENELITIAN}

Penelitian ini dilakukan di empat tempat yaitu Wood Work Shop dan Laboratorium Teknologi Kayu Fakultas Kehutanan Untan Pontianak, Laboratorium Kimia Fakultas MIPA Untan Pontianak, serta Laboratorium Mikrobiologi Unit Laboratorium Kesehatan.

\section{Persiapan Sampel}

Penelitian ini dimulai dengan pembuatan serbuk kulit batang $M$. odorata Griff (diameter $\pm 25 \mathrm{~cm}$, umur pohon \pm 10 tahun) dengan menggunakan alat hammer mill (Qingdao Dahua Double Circle Machinery Co., LTD). Kulit batang diperoleh dari pohon $M$. odorata Griff yang diambil dari halaman rumah warga di Jalan Parit $\mathrm{H}$. Husin Komplek Disbun Blok A Pontianak. Serbuk yang diperoleh selanjutnya diayak dengan mesh screen (Endecotts LTD. London, England) lolos 40 mesh tertahan 60 mesh. Selanjutnya dilakukan pengujian kadar air dengan mengoven (Memmert, Germany) sebanyak 2 gram serbuk pada suhu $103 \pm 2^{\circ} \mathrm{C}$ sampai mencapai berat konstan (Manuhuwa, 2007). Penentuan persentase kadar air dapat dihitung menggunakan rumus:

Kadar air dihitung berdasarkan rumus:

$$
\mathrm{KA}=\frac{\mathrm{BA}-\mathrm{BKO}}{\mathrm{BKO}} \times 100 \%
$$

dimana :

$\mathrm{KA}=$ Kadar air (\%)

$\mathrm{BA}=$ Berat serbuk awal (gram)

$\mathrm{BKO}=$ Berat kering oven (gram)

\section{Ekstraksi Kulit Batang M. odorata \\ Griff}

Perhitungan Rendemen

Sebanyak 1 gram serbuk kulit batang $M$. odorata Griff dimasukkan ke dalam Erlenmeyer dan ditambahkan pelarut etanol $96 \%$ hingga tercapai perbandingan volume 1:30. Selanjutnya Erlenmeyer diletakkan di atas shaker (IKA KS 260 basic and control shaker, USA) untuk dimaserasi selama $1 \times 24$ jam pada suhu kamar. Setelah 24 jam, ekstrak disaring dengan menggunakan kertas saring meteran. Perlakuan ini diulang hingga diperoleh larutan ekstrak yang jernih dengan asumsi bahwa semua zat ekstraktif yang terlarut etanol dapat diperoleh. Ekstrak yang diperoleh selanjutnya diuapkan dengan waterbath (Memmert, Germany) hingga diperoleh ekstrak kering dan ditimbang (Mettler Toledo) untuk mengetahui rendemen ekstrak. Rendemen ekstrak dapat dihitung dengan menggunakan rumus berikut: (Rahmah, 2012).

Rendemen ekstrak $=\frac{a}{(1-x) b} \times 100 \%$ dimana : 


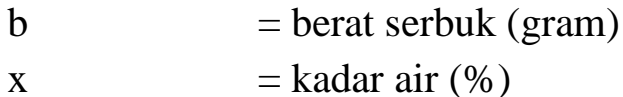

Pembuatan Ekstrak Kulit Batang M. odorata Griff

Pembuatan ekstrak kulit batang $M$. odorata Griff dilakukan dengan metode maserasi, dimana sebanyak 200 gram serbuk kulit batang M. odorata Griff dilarutkan dengan $1200 \mathrm{ml}$ pelarut etanol 96\% (perbandingan 1:6), diaduk selama 5 menit kemudian di shaker selama \pm 24 jam. Setelah 24 jam ekstrak kemudian disaring menggunakan kertas saring meteran, perlakuan tersebut diulangi hingga 4 kali. Selanjutnya filtrat diuapkan dengan rotary evaporator (Yamato Scientific Co., LTD, Japan) pada suhu $40-55^{\circ} \mathrm{C}$ sampai diperoleh ekstrak pekat kulit batang $M$. odorata Griff. Ekstrak pekat yang diperoleh selanjutnya diuapkan dengan waterbath hingga sisa-sisa pelarutnya teruap (Sangi, 2012).

\section{Skrining Fitokimia Ekstrak Etanol} Kulit Batang M. odorata Griff

Ekstrak etanol kulit batang $M$. odorata Griff di uji fitokimia untuk mengetahui keberadaan senyawa metabolit sekunder berupa fenolik, tanin, saponin, flavanoid, alkaloid, steroid dan terpenoid. Pengujian Fitokimia ekstrak kulit batang $M$. odorata Griff dilakukan mengikuti prosedur Harborne (1996) yang telah dimodifikasi. Persiapan ekstrak dimulai dengan memasukkan 1 gram ekstrak ekstrak kulit batang $M$. odorata Griff ke dalam tabung reaksi (Iwaki Pyrex, Japan) dan diencerkan dengan pelarut metanol sebanyak $\pm 10 \mathrm{ml}$ (Mailuhu et al. 2017).

\section{Uji Alkaloid}

Ekstrak kulit batang $M$. odorata Griff sebanyak $1 \mathrm{ml}$ dimasukkan ke dalam 3 tabung reaksi. Selanjutnya pada masing-masing tabung ditambahkan 10 tetes $\mathrm{H}_{2} \mathrm{SO}_{4} 2 \mathrm{~N}$ dan dikocok kuat. Kemudian ditambahkan pereaksi ke dalam masing-masing tabung reaksi, untuk tabung pertama ditambahkan pereaksi Dragendorff, tabung kedua ditambahkan pereaksi Wagner, dan tabung ketiga ditambahkan pereaksi Meyer. Terbentuknya endapan mengindikasikan bahwa ekstrak tersebut mengandung senyawa alkaloid. Hasil positif bila dengan pereaksi Dragendorff menghasilkan endapan berwarna merah jingga, dengan pereaksi Wagner menghasilkan endapan berwarna coklat, dan dengan perekasi Meyer menghasilkan endapan berwarna putih (Mailuhu et al. 2017).

Uji Saponin

Diambil sebanyak $1 \mathrm{ml}$ ekstrak kulit batang $M$. odorata Griff ke dalam tabung reaksi dan ditambahkan dengan $5 \mathrm{~mL}$ air panas sambil dikocok kuat selama 1 menit, kemudian ditambahkan 2 tetes $\mathrm{HCl} 2 \mathrm{~N}$. Hasil teruji mengandung saponin apabila menghasilkan busa yang tetap stabil selama kurang lebih 10 menit (Mailuhu et al. 2017).

\section{Uji Terpenoid dan Steroid}

Ekstrak kulit batang $M$. odorata Griff diteteskan ke tiga titik pada plat tetes (titik pertama sebagai standart, kedua sebagai terpenoid dan ketiga sebagai steroid) dan biarkan hingga 
kering. Setelah kering pada masingmasing titik plat ditetesi dengan larutan Liebermann-Buchard dan dietil eter sebanyak 2 tetes. Ekstrak positif mengandung steroid apabila titik tersebut menghasilkan warna biru atau hijau, sedangkan triterpenoid menghasilkan warna merah atau ungu (Sangi et al. 2008).

Uji Fenolik

$\mathrm{FeCl}_{3} \quad 1 \%$ sebanyak $2-3$ tetes ditambahkan ke dalam tabung reaksi yang telah berisi $1 \mathrm{ml}$ ekstrak kulit batang $M$. odorata Griff. Ekstrak positif mengandung senyawa fenol apabila menghasilkan warna biru kehitaman (Mailuhu et al. 2017).

Uji Tanin

$\mathrm{FeCl}_{3} \quad 1 \%$ sebanyak 10 tetes ditambahkan ke dalam tabung reaksi yang telah berisi $1 \mathrm{ml}$ ekstrak kulit batang M. odorata Griff. Ekstrak positif mengandung tanin apabila menghasilkan warna hijau kehitaman atau biru kehitaman (Harborne, 1987).

Uji Flavonoid

Uji Flavonoid dengan $\mathrm{HCl}$ Pekat dan Logam Magnesium

Diambil $1 \mathrm{ml}$ ekstrak kulit batang M. odorata Griff dan dimasukkan ke tabung reaksi, kemudian ditambahkan 2 tetes HCL pekat sambil dikocok kuat. Selanjutnya, ditambahkan serbuk magnesium (Mg) dan dikocok kuat. Buih yang dihasilkan dengan intensitas yang banyak dan larutan menjadi berwarna jingga menunjukkan bahwa ekstrak positif mengandung flavonoid (Mailuhu et al. 2017).

Uji Flavonoid dengan $\mathrm{H}_{2} \mathrm{SO}_{4}$
Sebanyak 2 tetes $\mathrm{H}_{2} \mathrm{SO}_{4} \quad 2 \quad \mathrm{~N}$ ditambahkan ke dalam tabung reaksi yang berisi $1 \mathrm{ml}$ ekstrak kulit batang $M$. odorata Griff, kemudian dikocok kuat. Ekstrak positif mengandung flavonoid apabila larutan menghasilkan warna kuning, merah, atau coklat (Mailuhu et al. 2017).

\section{Uji Flavonoid dengan NaOH $10 \%$}

Sebanyak $1 \mathrm{ml}$ ekstrak kulit batang M. odorata Griff dimasukkan ke dalam tabung reaksi, kemudian ditambahkan sebanyak 2 tetes $\mathrm{NaOH} 10 \%$ sambil dikocok kuat. Warna kuning, merah, coklat, atau hijau yang dihasilkan menunjukkan bahwa ekstrak positif mengandung flavonoid (Mailuhu et al. 2017).

\section{Pembuatan Media Plate Count Agar (PCA)}

Pada penelitian ini media yang digunakan adalah PCA (Plate Count Agar). Sebanyak 17,5 gram serbuk media PCA dilarutkan dengan air aquades steril hingga $1000 \mathrm{~mL}$ dan selanjutnya didihkan diatas hot plate (D-Lab MS7 H550) hingga homogen. Setelah mendidih kemudian disterilkan di dalam autoclave (Hirayama, Japan) pada suhu $121^{\circ} \mathrm{C}$ selama 15 menit dengan tekanan di atas 1 atm (Oxoid LTD, Basingstoke, Hampshire, England).

Pembuatan Standar Kekeruhan Larutan (Larutan Mc. Farland)

Sebanyak 9,9 ml larutan $\mathrm{H}_{2} \mathrm{SO}_{4} \quad 1 \%$ ditambahkan ke dalam tabung reaksi yang berisi $0,1 \mathrm{ml}$ larutan $\mathrm{BaCl}_{2}$ 1,175 $\%$, dan dikocok sampai terbentuk larutan yang keruh. Kekeruhan ini dipakai sebagai standar kekeruhan 
suspensi bakteri uji. Standar kekeruhan larutan yang digunakan yaitu Mc. Farland No. 1, dimana setara dengan $300 \times 10^{6} \mathrm{CFU} / \mathrm{ml}$ (Fatisa, 2013).

\section{Uji Aktivitas Antibakteri}

Pengujian aktivitas antibakteri pada penelitian ini dilakukan dengan metode difusi (disc diffusion Kirby and Bauer). Sebanyak 5-6 ml media PCA yang telah disterilkan dimasukkan kedalam masing-masing cawan petri (Pyrex, Germany) sampai media menjadi padat. Bakteri E. coli ATCC 25922 dan S. aureus ATCC 25923 yang sudah disetarakan dengan standar kekeruhan Mc. Farland No. 1 diswab menggunakan jarum ose steril pada media pertumbuhan PCA. Selanjutnya Kertas cakram Whatman No. 3 yang berdiameter $6 \mathrm{~mm}$ ditetesi dengan masing-masing konsentrasi ekstrak kulit batang $M$. odorata Griff menggunakan mikropipet (Socorex) sebanyak $20 \mu \mathrm{l}$ kemudian diletakkan diatas permukaan media PCA yang telah tersuspensi bakteri uji secara steril di dalam laminar air flow (Airstream). Masing-masing cawan petri diinkubasi (Memmert, Germany) dengan suhu $37^{\circ} \mathrm{C}$ selama 18 24 jam. Pengujian ini terdiri dari 6 perlakuan pada setiap bakteri uji, yaitu : 4 konsentrasi ekstrak kulit batang $M$. odorata Griff $(50 \mathrm{mg} / \mathrm{ml}, 100 \mathrm{mg} / \mathrm{ml}$, $150 \mathrm{mg} / \mathrm{ml}$ dan $200 \mathrm{mg} / \mathrm{ml}$ ), 1 kontrol negatif (etanol) dan 1 kontrol positif (tetracycline $30 \mu \mathrm{g}$ (Oxoid LTD, Basingstoke, England)) pada E. coli ATCC 25922. Empat konsentrasi ekstrak kulit batang $M$. odorata Griff (1 $\mathrm{mg} / \mathrm{ml}, 5 \mathrm{mg} / \mathrm{ml}, 10 \mathrm{mg} / \mathrm{ml}$ dan 15 $\mathrm{mg} / \mathrm{ml}$ ), 1 kontrol negatif (etanol) dan 1 kontrol positif (tetracycline) pada $S$. aureus ATCC 25923. Pengujian dilakukan dengan 3 kali ulangan (Rhimou et al. 2010). Diameter daerah hambat atau daerah bening (clear zone) yang terbentuk akan diukur dengan mistar. Data hasil pengukuran diameter daerah hambat pada bakteri uji di analisis secara statistik dalam bentuk Rancangan Acak Lengkap (RAL), apabila berpengaruh sangat nyata dan nyata maka dilanjutkan dengan uji Beda Nyata Jujur (BNJ) (Gaspersz, 2006).

HASIL DAN PEMBAHASAN Rendemen Ekstrak Etanol Kulit Batang M. odorata Griff

Proses ekstraksi merupakan tahap pendahuluan dalam penelitian ini, dimana rendemen ekstrak yang didapat sebesar 20,61 \% dengan kadar air sebesar 8,34 \%. Data hasil ektraksi tersaji secara lengkap pada Tabel 1.

Tabel 1. Hasil ekstraksi kulit batang M. odorata Griff (Results of extraction from M. odorata Griff bark)

\begin{tabular}{cccc}
\hline $\begin{array}{c}\text { Berat Serbuk } \\
(\mathbf{g})\end{array}$ & $\begin{array}{c}\text { Kadar Air } \\
(\boldsymbol{\%})\end{array}$ & $\begin{array}{c}\text { Berat Ekstrak } \\
(\mathbf{g})\end{array}$ & $\begin{array}{c}\text { Rendemen Ekstrak } \\
(\boldsymbol{\%})\end{array}$ \\
\hline 200 & 8,34 & 40,5018 & 20,61 \\
\hline
\end{tabular}

Berdasarkan klasifikasi komponen kimia kayu Indonesia, maka rendemen ekstrak etanol kulit batang M. odorta Griff termasuk ke dalam kelas kayu yang mengandung kadar zat ekstraktif tinggi karena rendemen ekstraknya lebih dari $4 \%$ 
(Departemen Pertanian, 1976). Persentase rendemen ekstrak yang dihasilkan pada penelitian ini lebih tinggi apabila dibandingkan dengan penelitian terdahulu yang juga menggunakan kulit batang $M$. odorata Griff dengan pelarut metanol, yang menghasilkan rendemen ekstrak sebesar 2\% (Lukmandaru et al. 2012).

Menurut Azis (2014) etanol merupakan pelarut dengan tingkat kepolaran yang tinggi. Etanol memiliki gugus - $\mathrm{OH}$ yang bersifat polar dan gugus $\mathrm{CH}_{2} \mathrm{CH}_{3}$ yang bersifat non polar, sifat non polar inilah yang membuat etanol mampu mengekstrak kandungan minyak, atsiri, dan alkaloid sehingga penggunaan etanol sebagai pelarut dalam proses ekstraksi diduga menyebabkan tingginya rendemen M. odorta Griff yang diperoleh pada penelitian ini. Selain faktor pemilihan jenis pelarut, tingginya rendemen juga dipengaruhi oleh bagian tanaman yang digunakan dalam pembuatan ekstrak. Pohon memiliki variabilitas yang tinggi terhadap komponen kimianya. Variabilitas ini tidak hanya terjadi antar jenis melainkan juga terjadi pada jenis yang sama dengan bagian yang berbeda (Sjostrom, 1995). Haygreen dan Bowyer
(1989), mengemukakan bahwa kandungan ekstraktif dalam kulit batang kayu lebih tinggi daripada bagian dalam kayu, dan hal ini telah dibuktikan oleh beberapa penelitian terdahulu (Lukmandaru et al. 2012).

\section{Skrining Fitokimia}

Skrining fitokimia merupakan suatu langkah awal yang penting dilakukan untuk mendeteksi keberadaan golongan senyawa metabolit sekunder yang terdapat pada suatu bahan alam (Sa'adah dan Nurhasnawati, 2015). Uji ini dapat dilakukan secara kualitatif maupun kuantitatif. Pada penelitian ini dilakukan pendeteksian senyawa metabolit sekunder secara kualitatif dengan melarutkan ekstrak M. odorata Griff dengan beberapa pereaksi sesuai dengan golongan senyawa yang diinginkan. Hasil uji fitokimia menunjukkan bahwa ekstrak etanol kulit batang $M$. odorata Griff positif mengandung senyawa kimia alkaloid, flavonoid, tanin, terpenoid, fenolik dan saponin. Akan tetapi tidak ditemukan senyawa steroid pada ekstrak tersebut. Selengkapnya, hasil skrining fitokimia tersaji pada Tabel 2.

Tabel 2. Hasil uji skrining fitokima (Phytochemical screening test results)

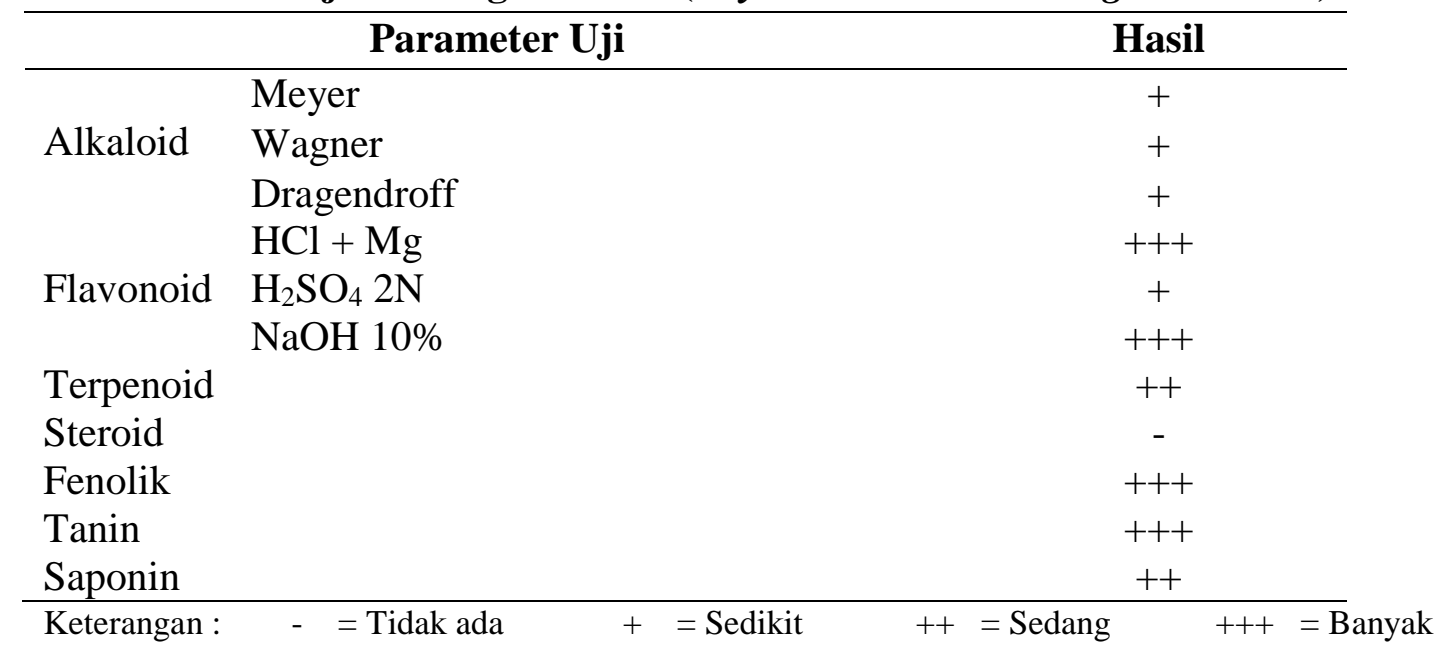




\section{Uji Aktivitas Antibakteri}

Pengujian ini menggunakan kontrol negatif (etanol 96\%) dan kontrol positif (tetracycline). Penggunaan pelarut etanol 96\% dipertimbangkan karena etanol merupakan pelarut awal pada proses pembuatan ekstrak, selain itu etanol bersifat netral, tidak beracun, dan penyerapannya baik, serta kapang dan kuman sulit tumbuh dalam etanol 20\% ke atas (Sa'adah dan Nurhasnawati, 2015). Antibiotik tetracycline dipilih sebagai kontrol positif dikarenakan tetracycline merupakan antibiotik yang umumnya sering digunakan oleh masyarakat untuk mengatasi infeksi bakteri dan memiliki harga yang murah. Penelitian Rahmah et al. (2012) memaparkan bahwa melalui penghambatan sintesis protein pada ribosom, tetracycline menjadi antibiotik yang terbukti efektif untuk menghambat pertumbuhan bakteri $E$. coli dan $S$. aureus dibandingkan amoxicillin dan ampicillin.

Pengujian pada penelitian ini dilakukan dengan menggunakan 2 bakteri yang berbeda yaitu, bakteri $E$. coli dan $S$. aureus. Berdasarkan pengujian yang telah dilakukan didapatkan hasil bahwa ekstrak etanol kulit batang $M$. odorata Griff mampu menghambat pertumbuhan bakteri $E$. coli dan S. aureus.

Uji Aktivitas Antibakteri Pada Bakteri Uji S. aureus ATCC 25923

Berdasarkan hasil yang diperoleh pada pengujian didapatkan hasil bahwa semua konsentrasi ekstrak etanol kulit batang $M$. odorata Griff dapat menghambat pertumbuhan bakteri $S$. aureus. Rerata diameter zona hambat esktrak etanol kulit batang $M$. odorata Griff terhadap pertumbuhan bakteri $S$. aureus selengkapnya disajikan pada Gambar 1.

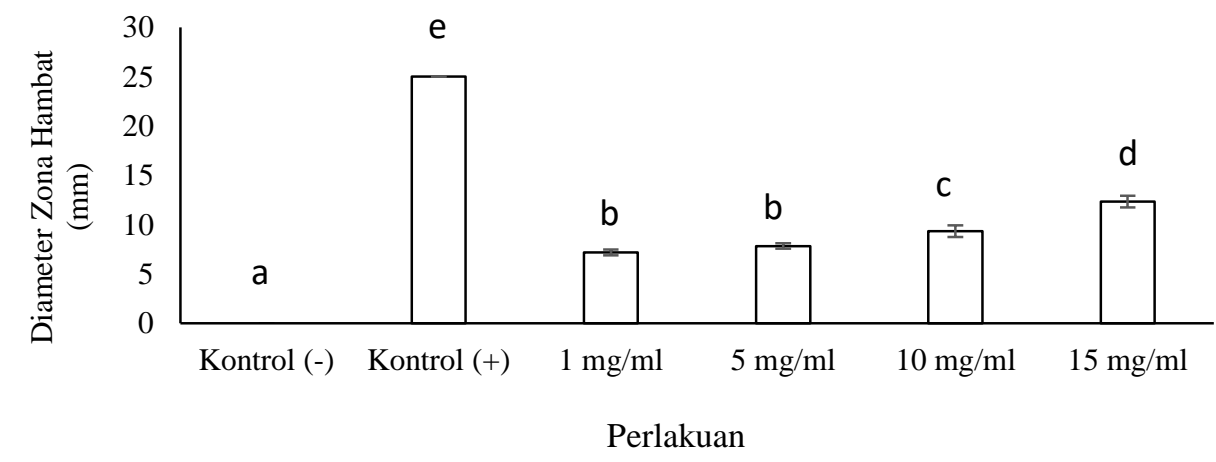

Gambar 1. Rerata dan standar deviasi diameter zona hambat uji ekstrak etanol kulit batang $M$. odorata Griff terhadap pertumbuhan bakteri S. aureus ATCC 25923, rerata yang diikuti huruf yang sama tidak berbeda nyata pada taraf $1 \%$ atau $5 \%$ ) (Mean and standard deviation of diameter inhibition zone of ethanol extract of M. odorata Griff wood bark against the growth bacteria of S. aureus ATCC 25923, the mean followed by the same letter is not significantly different at the level of 1\%).

Pada Gambar 1 diatas terlihat yang dihasilkan, walaupun pada hasil bahwa semakin tinggi konsentrasi uji lanjut beda nyata jujur (BNJ) ekstrak semakin besar zona hambatan menunjukkan bahwa pada konsentrasi 1 
$\mathrm{mg} / \mathrm{ml}$ tidak berbeda nyata dengan konsentrasi $5 \mathrm{mg} / \mathrm{ml}$. Respon hambatan bakteri $S$. aureus hasil penelitian ini diklasifikasikan menurut Davis dan Stout (1971), respon hambatan yang sedang ditunjukkan oleh konsentrasi 1 $\mathrm{mg} / \mathrm{ml}(7,17 \mathrm{~mm}), 5 \mathrm{mg} / \mathrm{ml}(7,83 \mathrm{~mm})$, dan $10 \mathrm{mg} / \mathrm{ml}$, sedangkan pada konsentrasi $15 \mathrm{mg} / \mathrm{ml} \quad(12,33 \mathrm{~mm})$ memiliki respon hambatan yang kuat. Hasil penelitian ini sesuai dengan penelitian terdahulu yang dilakukan oleh Suerni (2013), yang memaparkan bahwa ekstrak buah $M$. odorata Griff mampu menghambat pertumbuhan $S$. aureus dengan konsentrasi $50 \%$ sebesar $7 \mathrm{~mm}$ dan $100 \%$ sebesar 8,6667 mm (Gambar 2).

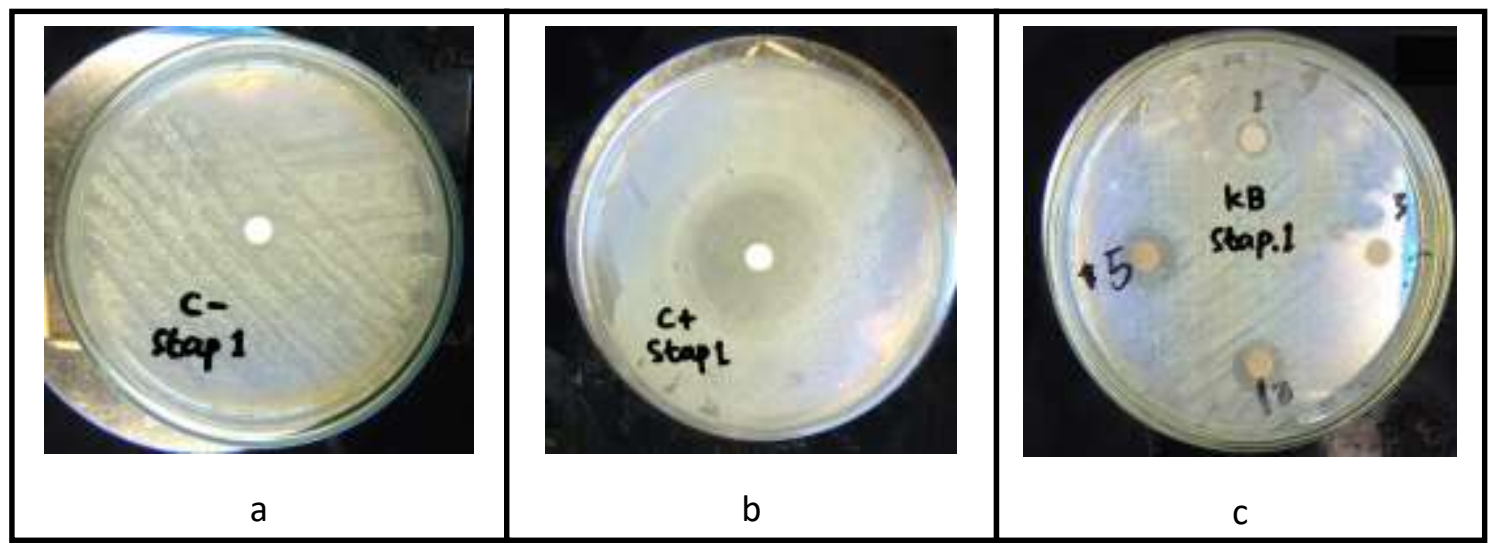

Gambar 2. Hasil uji ekstrak etanol kulit batang M. odorata Griff terhadap bakteri $S$. aureu ATCC 25923: a. kontrol negatif (etanol 96\%); b. kontrol positif (tetracycline $30 \mu \mathrm{g}$ ); c. konsentrasi ekstrak (1 mg/ml, $5 \mathrm{mg} / \mathrm{ml}, 10 \mathrm{mg} / \mathrm{ml}$, dan $15 \mathrm{mg} / \mathrm{ml}$ ) (Test results of ethanol extract of M. odorata Griff bark against on bacteria of S. aureus ATCC 25923: a. negative control (96\% ethanol); b. positive control (tetracycline $30 \mu \mathrm{g})$; c. extract's concentration (1 $\mathrm{mg} / \mathrm{ml}, 5 \mathrm{mg} / \mathrm{ml}, 10 \mathrm{mg} / \mathrm{ml}$, and $15 \mathrm{mg} / \mathrm{ml})$ )

Tinggi rendahnya suatu antibakteri dalam menghasilkan zona hambat sangatlah dipengaruhi oleh zat antibakteri yang terkandung pada ekstrak yang digunakan. Dari hasil uji skrining fitokimia yang telah dilakukan maka diketahui bahwa ekstrak etanol kulit batang $M$. odorata Griff mengandung senyawa alkaloid, flavonoid, fenolik, tanin, terpenoid dan saponin, dimana senyawa-senyawa tersebut dapat menghambat pertumbuhan bakteri (Suerni, 2013).

Pada ekstrak etanol kulit batang $M$. odorata Griff mengandung flavonoid dalam jumlah banyak. Flavonoid merupakan senyawa metabolit sekunder yang bersifat antimikroba dan efektif dalam menghambat pertumbuhan bakteri Gram positif. S. aureus merupakan salah satu bakteri Gram positif memiliki dinding sel yang bersifat polar. Lapisan peptidoglikan yang bersifat polar ini akan dapat dengan mudah ditembus oleh senyawa flavonoid yang juga bersifat polar (Suerni, 2013). Sabir (2005) menambahkan bahwa senyawa flavonoid akan berikatan dengan protein fungsional sel dan DNA bakteri yang berakibat pada rusaknya permeabilitas dinding sel mikroba.

Ekstrak etanol kulit batang $M$. odorata Griff juga mengandung 
senyawa fenolik dan tanin dalam jumlah yang banyak. Senyawa metabolit sekunder terbanyak yang terdapat pada spesies tumbuhan di dunia adalah senyawa fenolik. Menurut Cowan (1999), senyawa fenolik dapat menghambat pertumbuhan bakteri karena dapat mengoksidasi bakteri dengan beberapa cara yaitu menghancurkan dinding sel bakteri, menghilangkan substrat, menonaktifkan enzim dan berikatan dengan adhesin yang merupakan protein pada bakteri.

Tanin merupakan salah satu senyawa golongan polifenol yang dapat berikatan secara kompleks dengan protein, polisakarida, alkaloid, asam nukleat, mineral dan lain-lain baik secara reversibel maupun irreversible yang dapat menyebabkan kerusakan pada sel bakteri (Ajizah, 2004). Mekanisme kerja tanin sebagai antibakteri adalah dengan cara merusak membran sel bakteri, senyawa astringent tanin dapat menginduksi pembentukan kompleks senyawa ikatan terhadap enzim atau subtrat mikroba (Karlina et al. 2013).

Senyawa metabolit lain yang memiliki aktivitas sebagai antimikroba dan ditemukan pada ekstrak etanol kulit batang $M$. odorata Griff adalah terpenoid, saponin dan alkaloid. Terpenoid dikenal sebagai senyawa metabolit sekunder yang mampu menghambat pertumbuhan bakteri, fungi, virus dan protozoa. Terpenoid mampu merusak lapisan dinding sel dengan cara menggumpalkan protein bakteri yang mengakibatkan terjadinya gangguan pada tekanan osmosis sel bakteri (Suerni, 2013).

Melalui mekanisme peningkatan permeabilitas membran sel bakteri, senyawa saponin menghambat pertumbuhan bakteri. Ekstrak uji yang mengandung saponin dalam konsentrasi yang rendah akan dapat mengganggu permeabilitas sel, seiring dengan kenaikan konsentrasi saponin pada ekstrak uji akan dapat menyebabkan kematian dari sel yang dikarenakan hancurnya membran sel bakteri.

Keberadaan alkaloid pada ekstrak etanol kulit batang $M$. odorata Griff jumlahnya sedikit, sehingga kemungkinan besar senyawa alkaloid tidak terlalu berperan dalam menghambat pertumbuhan bakteri $S$. aureus maupun E. coli. Alkaloid merupakan senyawa nitrogen yang umumnya sering digunakan dalam bidang pengobatan. Hal ini dikarenakan alkaloid memiliki kemampuan bioaktivitas dan memiliki aktivitas fisiologi yang tinggi (Mustikasari, 2010). Alkaloid bekerja sebagai senyawa antibakteri dengan cara berinteraksi dengan dinding dan DNA sel bakteri (Cushnie dan Lamb, 2005).

Uji Aktivitas Antibakteri Pada Bakteri Uji E. coli ATCC 25922

Berdasarkan penelitian yang telah dilakukan dapat dikatakan bahwa ekstrak etanol kulit batang $M$. odorata Griff mampu menghambat pertumbuhan bakteri $S$. aureus lebih baik daripada bakteri E.coli. Hal ini diduga karena $E$. coli merupakan bakteri Gram negatif yang secara alamiah memiliki resistensi yang tinggi terhadap antibakteri. Oleh 
karena itu, pada penelitian ini digunakan konsentrasi yang berbeda untuk kedua jenis bakteri uji. Rerata diameter zona hambat esktrak etanol kulit batang $M$. odorata Griff terhadap pertumbuhan bakteri E. coli selengkapnya disajikan pada Gambar 3.

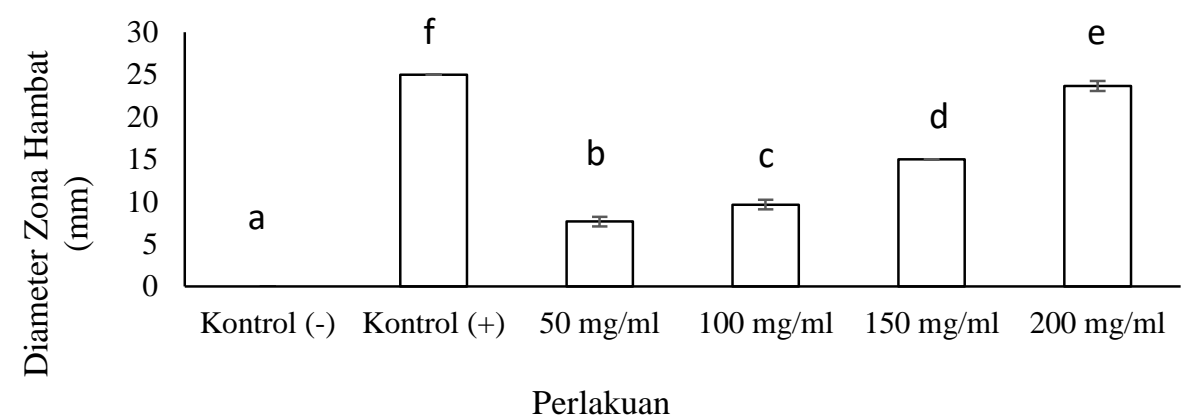

Gambar 3. Rerata dan standar deviasi diameter zona hambat uji ekstrak etanol kulit batang $M$. odorata Griff terhadap pertumbuhan bakteri $E$. coli ATCC 25922, rerata yang diikuti huruf berbeda menunjukkan bahwa setiap perlakuan berbeda sangat nyata pada taraf $1 \%$ (Mean and standard deviation of diameter inhibition zone of ethanol extract from $M$. odorata Griff bark against the growth bacteria of E. coli ATCC 25922, the mean followed by different letters showed that each treatment very significantly different at level of 1\%)

Hasil pengujian menyatakan bahwa setiap konsentrasi memiliki pengaruh yang berbeda dalam menghambat pertumbuhan bakteri E. coli. Semakin tinggi konsentrasi maka semakin besar diameter zona hambat yang dihasilkan (Gambar 4). Klasifikasi respon hambatan bakteri $E$. coli berdasarkan rerata diameter zona hambat yang dihasilkan menunjukkan bahwa konsentrasi $50 \mathrm{mg} / \mathrm{ml}$ (7,67 mm), 100 $\mathrm{mg} / \mathrm{ml} \quad(9,67 \mathrm{~mm})$ memiliki respon hambatan yang sedang, sedangkan pada konsentrasi $150 \mathrm{mg} / \mathrm{ml} \quad(15 \quad \mathrm{~mm})$ memiliki respon hambatan yang kuat, bahkan pada konsentrasi $200 \mathrm{mg} / \mathrm{ml}$ menunjukkan respon hambatan yang sangat kuat (Davis dan Stout, 1971).

E. coli merupakan golongan bakteri Gram negatif yang secara alamiah lebih resisten terhadap bahan antibakteri. Resistensi alami ini merupakan suatu mekanisme pertahanan yang dimiliki oleh bakteri terhadap antibiotik (Adila et al. 2013), sehingga ekstrak tumbuhan yang biasanya diujikan pada bakteri Gram positif akan menunjukkan efektivitas yang lebih tinggi dalam penghambatan pertumbuhan bakteri dibandingkan pada bakteri Gram negatif (Cimanga et al. 2002). Hal ini dikarenakan struktur dinding sel bakteri Gram positif memiliki kepadatan lapisan lipopolisakarida pada permukaan luar dinding sel yang lebih rendah dibandingkan dengan bakteri Gram negatif (Burn, 1988). Oleh karena itu, antibakteri yang diberikan pada bakteri Gram positif akan lebih mudah melalui lapisan peptidoglikan dinding sel bakteri dan menembus ke dalam sitoplasma yang akhirnya akan menyebabkan hilangnya tekanan turgor sel (Clements et al. 2002). 


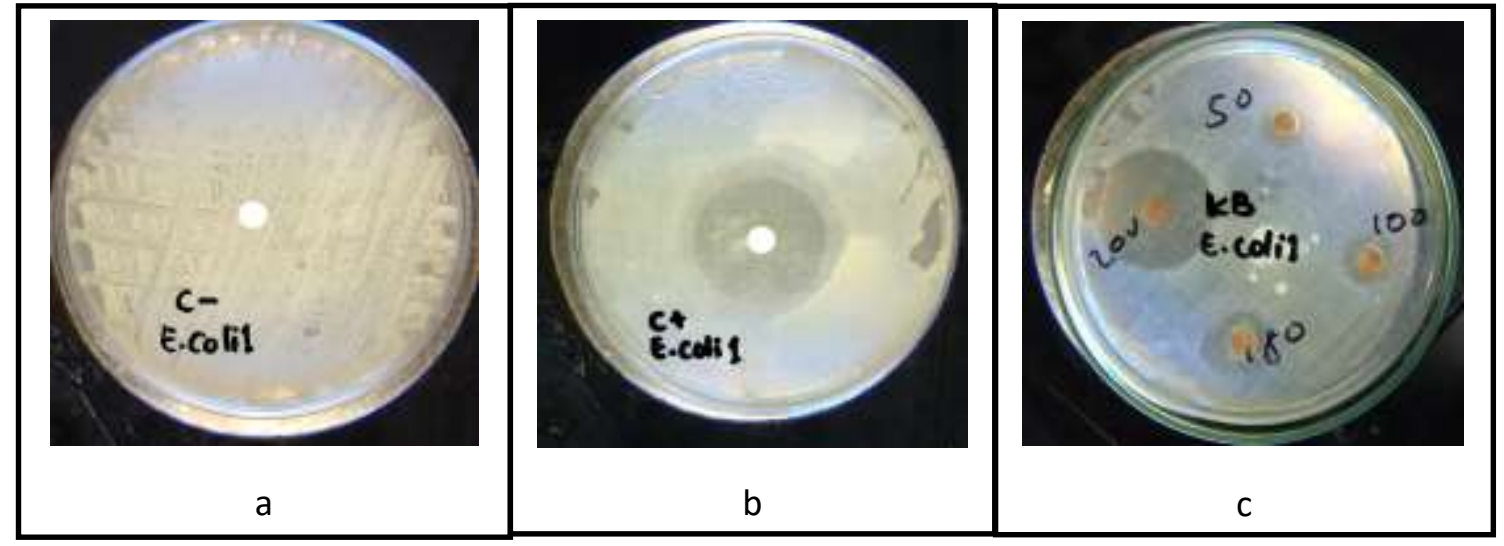

Gambar 4. Hasil uji ekstrak etanol kulit batang M. odorata Griff terhadap bakteri E. coli ATCC 25922: a. kontrol negatif (etanol 96\%); b. kontrol positif (tetracycline $30 \mu \mathrm{g}$ ); c. konsentrasi ekstrak $(50 \mathrm{mg} / \mathrm{ml}, 100 \mathrm{mg} / \mathrm{ml}, 150 \mathrm{mg} / \mathrm{ml}$, dan $200 \mathrm{mg} / \mathrm{ml})$ (Test results of ethanol extract of $M$. odorata Griff bark against on bacteria of E. coli ATCC 25922: a. negative control (96\% ethanol); b. positive control (tetracycline $30 \mu g) ;$ c. extract's concentration (50 $\mathrm{mg} / \mathrm{ml}, 100 \mathrm{mg} / \mathrm{ml}, 150 \mathrm{mg} / \mathrm{ml}$, and $200 \mathrm{mg} / \mathrm{ml}$ ))

Pelezar dan Chan (2006) menambahkan bahwa kompleksitas dari struktur penyusun dinding sel bakteri Gram negatif menyebabkan bakteri golongan ini lebih resisten terhadap antibakteri. Secara umum, bakteri Gram negatif termasuk E. coli memiliki dinding sel yang terdiri atas 3 lapisan yaitu lipoprotein, membran luar fosfolipid dan lipopolisakarida. Keberadaan membran luar fosfolipid pada bakteri Gram negatif menyebabkan senyawa yang bersifat antibakteri akan sulit menembus dinding sel bakteri (Poeloengan et al. 2007). Sebaliknya, bakteri gram positif pada umumnya memiliki dinding sel yang hanya terdiri dari 1 lapisan saja sehingga dengan mudah senyawa yang bersifat aktibakteri dapat menembus dinding sel.

Meskipun bakteri $E$. coli lebih resisten terhadap bahan antibakteri dibandingkan bakteri $S$. aureus, tetapi dengan peningkatan konsentrasi ekstrak membuat bakteri E. coli dapat dihambat pertumbuhannya bahkan pada konsentrasi
$200 \mathrm{mg} / \mathrm{ml}$ menghasilkan zona hambat yang mendekati hasil zona hambat untuk antibiotik tertacyline. Penelitian lain menggunakan ekstrak dari famili yang sama dengan pelarut yang berbeda yaitu ekstrak metanol $M$. indica $\mathrm{L}$ dengan konsentrasi $250 \mathrm{mg} / \mathrm{ml}$ menghasilkan diameter zona hambat yang lebih kecil yaitu sebesar $9 \mathrm{~mm}$ (Douhari dan Manzara, 2008). Pada bakteri E. coli, senyawa fenol bekerja dengan mendenaturasi protein dan merusak membran sel sehingga menyebabkan kematian pada bakteri (Harbone, 1978). Mekanisme kerja senyawa aktif antibakteri lainnya sama seperti yang telah dipaparkan sebelumnya.

\section{Kesimpulan}

Berdasarkan hasil penelitian dan pembahasan, maka dapat disimpulkan bahwa rendemen ekstrak etanol kulit batang M. odorata Griff sebesar 20,61\% dengan kadar air serbuk sebesar 8,34\%. Dari hasil skrining fitokimia menunjukan bahwa ekstrak etanol kulit batang $M$. 
odorata Griff positif mengandung senyawa metabolit sekunder golongan terpenoid, saponin, tanin, fenolik, flavonoid dan alkaloid, serta negatif steroid.

Ekstrak etanol kulit batang $M$. odorata Griff terbukti memiliki aktivitas antibakteri, hal ini dibuktikan dengan kemampuan ekstrak ini dalam menghambat pertumbuhan bakteri $E$. coli dan $S$. aureus, dimana konsentrasi 15 $\mathrm{mg} / \mathrm{ml}$ merupakan konsentrasi yang menghasilkan daya hambat pertumbuhan bakteri uji $S$. aureus terbesar sedangkan konsentrasi ekstrak $200 \mathrm{mg} / \mathrm{ml}$ pada bakteri uji $E$. coli menghasilkan daya hambat pertumbuhan terbesar dan hampir setara dengan antibiotik tetracycline $30 \mu \mathrm{g}$. Saran

Setelah dilakukan penelitian tentang pengaruh esktrak etanol kulit batang $M$. odorata Griff dalam menghambat pertumbuhan bakteri E. coli dan S. aureus, maka disarankan agar ekstrak etanol kulit batang $M$. odorata Griff dapat dijadikan bahan alternatif dalam pengobatan penyakit yang disebabkan oleh bakteri $E$. coli dan $S$. aureus. Selanjutnya, perlu adanya penelitian lanjutan guna mengetahui pengaruh ekstrak etanol kulit batang $M$. odorata Griff terhadap penyakit lain yang disebabkan oleh kapang dan jamur.

\section{Ucapan Terima Kasih}

Penulis berterima kasih kepada ibu Yeni Mariani, S.Hut, M.Sc, Ph.D (Dosen Fak. Kehutanan UNTAN) yang telah mempersiapkan bakteri uji. Penulis berterima kasih kepada Zaka Prihatin (Mahasiswa Fak. Kehutanan UNTAN) atas pemberian kulit kayu $M$. odorata Griff untuk sampel penelitian.

\section{DAFTAR PUSTAKA}

Adila, R, Nurmiati, dan Anthoni A. 2013. Uji Antimikroba Curcuma spp. Terhadap Pertumbuhan Candida albicans, Staphylococcus aureus, dan Escherichia coli. Jurnal Biologi Universitas Andalas. Vol 2 (1): 1-7. ISSN : 2303-2162.

Ajizah A. 2004. Sensitivitas Salmonella typhimurium Terhadap Ekstrak Daun Psidium guajava L. Journal Bioscientiae. Vol 1 (1): 31-38.

Azis T, Febrizky S dan Mario AD. 2014. Pengaruh Jenis Pelarut Terhadap Persen Yield Alkaloid Dari Daun Salam India (Murraya koenigii). Teknik Kimia. Vol 20 (2).

Burn P. 1988. Amphitropic proteins: A new class of membrane proteins. Trends in Biochemical Sciences. Vol 13: 79-83.

Candrasari A, Muhammad AR, Masna H, Ovi RA. 2012. Uji Daya Antimikroba Ekstrak Etanol Daun Sirih Merah (Piper crocatum Ruiz \& Pav.) Terhadap Pertumbuhan Staphylococcus aureus ATCC 6538, Eschericia coli ATCC 11229 dan Candida albicans ATCC 10231 Secara In Vitro. Jurnal Biomedika. Vol 4 (1): 9-16.

Cimanga, K, Kambu K, Tona L, Apers S, De Bruyne T, Hermans N, Tott'e J, Pieters L, dan Vlietinck AJ. 2002. Correlation Between Chemical Composition and Antibacterial Activity of Essential Oils of Some Aromatic Medicinal Plants Growing in The Democratic Republic of Congo. Journal of Ethnopharmacology. Vol 79: 213 220. 
Clements JM, Coignard F, Johnson I, Chandler S, Palan S, Waller A, Wijkmans J, dan Hunter MG. 2002. Antibacterial Activities and Characterization of Novel Inhibitors of LpxC. Antimicrobial Agents and Chemotherapy. Vol 4 (6): 1793 1799.

Cowan MM. 1999. Plant Products as Antimicrobial Agents. Clinical Microbiology Reviews. Vol 12 (4): $564-582$.

Cushnie TP dan Lamb AJ. 2005. Amtimicrobial Activity of Flavonoids. International Journal of Antimicrobial Agents. Vol 26: 343356.

Dart RK. 1996. Microbiology of The Analytical Chemist. The Royal Society of Chemistry. London.

Davis WW dan Stout TR. 1971. Disc Plate Method of Microbiological Antibiotic Assay. Journal Of Microbiology. Vol 22 (4):659-665.

Depkes RI. 2000. Parameter Standart Umum Ekstak Tumbuhan Obat. Departemen Kesehatan Republik Indonesia. Jakarta.

Departemen Pertanian. 1976. Vademecum Kehutanan Indonesia. Balai Penjelidikan Kehutanan. Jakarta.

Djajadisastra J, Abdul M, Dessy NP. 2009. Formulasi Gel Topikal Dari Ekstrak Nerii Folium Dalam Sediaan Anti Jerawat. Jurnal Farmasi Indonesia. Vol 4: 210 -216.

Doughari J dan Manzara S. 2008. In Vitro Antibacterial Activity of Crude Leaf Extracts of Mangifera indica Linn. African Journal of Microbiology Research. Vol 2 (1): 67-72.

Fatisa Y. 2013. Daya Antibakteri Kulit dan Biji Buah Pulasan (Nephelium mutabile) Terhadap Staphylococcus aureus dan Eschericia coli Secara In Vitro. Jurnal Peternakan. Vol 10: 31-38. ISSN 1829-8729.

Gaspersz V. 2006. Teknik Analisis Dalam Penelitian Percobaan. Jilid I Cetakan Ketiga. Tarsito. Bandung.

Harborne JB. 1978. Phytochemical methods (3rd edn).Chapman and Hall. London. pp 60: 135, 203.

Harborne JB. 1987. Metode Fitokimia, Penuntun Cara Modern Menganalisis Tumbuhan Edisi I, diterjemahkan Padmawinata $\mathrm{K}$ dan Soediro I. ITB. Bandung.

Harborne JB. 1996. Metode Fitokimia, Penuntun Cara Modern Menganalisis Tumbuhan Edisi II, diterjemahkan Padmawinata $\mathrm{K}$ dan Soediro I. ITB. Bandung.

Haygreen JG dan Bowyer JL. 1989. Hasil Hutan dan Ilmu Кауи, diterjemahkan Hadikusuma SA. Gajah Mada University Press. Yogyakarta.

Karlina CY, Ibrahim M, dan Trimulyono G. 2013. Aktivitas Antibakteri Ekstrak Herba Krokot (Portulaca oleracea L.) Terhadap Staphylococcus aureus dan Escherichia coli. LenteraBio. Vol 2(1):87-93. ISSN: 2252-3979

Kementerian Kesehatan RI. 2011. Situasi Diare di Indonesia. Buletin Jendela Data dan Informasi Kesehatan. ISSN 2088 - 270x.

Lukmandaru G, Kristian V, Anisa AG. 2012. Aktivitas Antioksidan Ekstrak Metanol Kayu Mangifera indica L., Mangifera foetida Lour, dan Mangifera odorata Griff. Jurnal Ilmu Kehutanan. Vol 6 (1) : 18-29. 
Mailuhu M, Runtuwene MRJ, Koleangan HSJ. 2017. Skrining Fitokimia dan Aktivitas Antiosidan Ekstrak Metanol Kulit Batang Soyogik (Saurauia bracteosa DC). Chem Prog. Vol 10:1.

Manuhuwa E. 2007. Kadar Air dan Berat Jenis Pada Posisi Aksial dan Radial Kayu Sukun (Arthocarpus communis, J.R dan G.Frest). Jurnal Agroforestri. Vol 2 (1).

Muskhazli M, Dirnahayu M, Azwady NAA, Nurhafiza Y, Dalilah NE. 2009. Antibacterial Activity of Methanolic Crude Extracts from Selected Plant Against Bacillus cereus. Jurnal Pertanika J. Trop. Agric. Sci. Vol 32 (2) : 175-183. ISSN : 1511-3701.

Mustikasari K dan Ariyani D. 2010)\. Skrining Fitokimia Ekstrak Metanol Biji Kalangkala (Litseaangulata). Sains dan Terapan Kimia. Vol 4 (2): 131-136.

Pelezar MJ dan Chan ECS. 2006. DasarDasar Mikrobiologi (I). UI Press. Jakarta.

Poeloengan M, Andriani, Susan MN, Komala I, Hasnita M. 2007. Uji Daya Antibakteri Ekstrak Etanol Kulit Batang Bungur (Largerstoremia speciosa Pers.) Terhadap Staphylococcus aureus dan Escherichia coli Secara In Vitro. Seminar Nasional Teknologi Peternakan dan Veteriner.

Rahmah SA, Suharti, Subandi. 2012. Uji Antibakteri dan Daya Inhibisi Ekstra Kulit Manggis (Garcinia mangostana L.) Terhadap Aktivitas Xantin Aksidase yang Diisolasi dari Air Susu Sapi Segar. Jurnal Online Kimia Universitas Malang. Vol 1 (1).
Rhimou B, Hassane R, Jose M, Nathalie B. 2010. The Antibacterial Potential of The Seaweeds (Rhodophyceae) of The Strait of Gibraltar and The Mediterranean Coast of Morocco. African Journal of Biotechnology. Vol 9 (38): 6365-6372. ISSN: 16845315.

Sabir A. 2005. Aktivitas Antibakteri Flavonoid Propolis Trigona $s p$. Terhadap Bakteri Streptococcus mutans (in vitro). Jurnal Kedokteran Gigi. Vol 38 (3): 135-141.

Sangi M, Runtuwene MRJ, Simbala HE, Makang VA. 2008. Analisis Fitokimia Tumbuhan Obat di Kabupaten Minahasa Utara. Chem Prog.Vol 1 (1).

Sangi MS, Momuat L, Kumaunang M. 2012. Uji Toksisitas dan Skrinning Fitokimia Tepung Gabah Pelepah Aren (Arenga pinnata). Jurnal Ilmiah Sains. Vol 12 (2): 128-134.

Santoso RM, Praharani D, Purwanto. 2012. Daya Antibakteri Ekstrak Daun Pare (Momordica charantia) dalam Menghambat Pertumbuhan Streptococcus viridans. Artikel Ilmiah Hasil Penelitian Mahasiswa.

Sa'adah H dan Nurhasnawati H. 2015. Perbandingan Pelarut Etanol dan Air Pada Pembuatan Ekstrak Umbi Bawang Tiwai (Eleutherine americana). Jurnal Ilmiah Manuntung. Vol 1 (2):149-153. ISSN 2477-1821.

Sjostrom E. 1995. Kimia Kayu : DasarDasar dan Penggunaan Jilid 2. Gadjah Mada University Press. Yogyakarta.

Suerni E, Alwi M, Guli MM. 2013. Uji Daya Hambat Ekstrak Buah Nanas (Ananas comosus L. Merr.), Salak (Salacca edulis Reinw.) dan 
JURNAL TENGKAWANG (2018)

Vol. 8 (2) : 59 - 74

Mangga Kweni (Mangifera odorata Griff.) Terhadap Daya Hambat Staphylococcus aureus. Jurnal Biocelebes. Vol 7 (1): 35-47. ISSN: 1978-6417.
Yang D, Pornpattananangkul D, Nakatsuji T, Chan M, Carson D, Huang CM. 2009. The Antimicrobial Activity of Liposomal Lauric Acids Against Proponibacterium acnes. Biomaterials. Vol 30: 6035-6040. 